\title{
Translanguaging in an EFL classroom discourse: To what extent it is helpful for the students?
}

\author{
Dinda Gusti Ayu Berlianti, Intan Pradita* \\ Department of English Language Education, Universitas Islam Indonesia, Yogyakarta 55584, Indonesia
}

Article history:

Received: 13 June 2021 / Received in revised form: 27 June 2021 / Accepted: 28 June 2021

\begin{abstract}
Translanguaging is a tool for bilingual or multilingual to learn more than one language. In the field of linguistic, translanguaging is not something new. However, its implementation is still found rare in higher education. To fill this void, this study aims to investigate the implementation of translanguaging in classroom, especially in higher education. This research was intended to answer how helpful translanguaging practices in EFL Classroom is. By using qualitative method, the data were collected by recording two credits full face-to-face classroom interaction. One lecturer and her forty-five students voluntarily became the research participants. The data were then analyzed by using thematic analysis. The findings showed that the practices were helpful in a way that the tutors could build an engaging dialogue for the students, enabling them to understand the complex learning materials. These findings then implied that in the teaching and learning process, EFL lecturers tend to be more attentive as they prefer to have their students understanding on complex subject to build English proficiency of their students'.
\end{abstract}

Keywords: translanguaging; code-switching; higher education.

\section{Introduction}

The current empirical evidence of translanguaging practice in English as Foreign Languages classroom focuses on supporting the teaching of a multilingual student on students; language practices, especially on immigrant students (Daniel \& Pacheco, 2016). Translanguaging has been intended to be a way of acknowledging the students' language practices more flexible and dynamic, and as a means to influence the meaningmaking communicative system of all students at the beginning of school (Garcia, Ofelia; Wei, 2018). In addition, translanguaging has some pedagogical strategies, which make the bilingual students and lecturer engaged in a knowledge construction through the flexible use of their linguistic repertoire irrespective of what named languages they now (Garcia; Wei, 2018).

On the other hand, translanguaging in the classroom is potential to deepen an understanding on socio-political engagement, develop critical thinking, and extend metalinguistic awareness and cross-linguistic flexibility. Moreover, it can engage between the lecturer and students (Creese \& Blackledge, 2015). It can then be stated that translanguaging brings a positive impact as an approach in the classroom. Currently, the application of English language in

Corresponding author.

Email: intan.pradita@uii.ac.id

https://doi.org/10.21924/chss.1.1.2021.14
Indonesia attracts a special attention. Many people have used it from elementary school until university. Moreover, English becomes a subject that is included in the national exam. In its implementation, translanguaging practice helps the English language learning in the context of EFL classroom in Indonesia (Rasman, 2018). In Indonesia, most English lecturers have employed Bahasa Indonesia and English as translanguaging practice and some lecturer have used the regional languages (Javanese, or Sudanese). The previous studies revealed that the use of translanguaging practice in the classroom has been examined by some higher education based upon the perspective of the immigrant students from Panjabi. As one of the immigrant students in Birmingham, translanguaging is perceived as a practice that can engage learners (Creese \& Blackledge, 2015). A similar case is found in United States where translanguaging was used to support students' practice and the lecturer should make some efforts to implement translanguaging to know their students (Daniel \& Pacheco, 2016). Although it has been a study on translanguaging in a higher education context, it is still in the context of diploma degree students. However, studies about Translanguaging in EFL under graduate classroom are still rarely found. Thus, to fill the gap, the researcher would extend the discussion on practical level of translanguaging in classroom discourses. This research clarified two questions:

1) What types of translanguaging practices that have been prominently used by EFL lecturer in the classroom? 
2) To what extent translanguaging practices are helpful for EFL undergraduate students?

\subsection{Translanguaging practices}

The term translanguaging is a concept of communication that uses more than one language. This is emphasized by Canagarajah (2011) submitting that translanguaging makes multilingual communication more varied, dynamic, and independent than monolingual. Rasman (2018) stated that the concept of translanguaging reflects some significant changes in conceptualization and multilingual language that emphasize on the importance of using a full linguistic repertoire. In addition, translanguaging in the classroom has a meaning in a process in which the students and the lecturer can engage in developing the new language practices (Creese \& Blackdge, 2015).

Thus, Translanguaging is an increasingly important area in the applied linguistics and classroom practices. Tse (1996) stated that translanguaging practices include code-switching, language brokering, translation and interpreting. $\mathrm{Li}$ and Tse (2002) stated that code-switching has focused on a spontaneous conversation and is written in two different languages. As argued by Moore (2002) there are two functions of codeswitching, i.e. first, to clarify the fact that they understand each other at the communicative level from convergence to student language selections, and that students do response questions and therefore do their work as students, and second, when the classroom has a rule, which entitles to use of the second language.

As stated by Hoffman (2014) there are four types of codeswitching: (a) Inter-sentential switching that is when the speaker starts with first language in completed sentence and then switch the next sentence in other language; (b) Intrasentential switching that is when the speaker switches from one language to other language at clause, phrase, or word level within a single utterance; (c) Tag switching that is when the speaker switches only insertion of a word or tag in one language in a sentence, which is entirely in other language (like you know, so, I mean, right?) and (d) Establishing continuity with the previous speaker that is when the speaker continues to speak the most recently language used because of a triggered effect.

The previous study by Moore (2010) emphasized that inter and intra-sentential switching occur in the classroom, especially with young children at early learning stages. Tse (1996) defined that language brokering facilitates to communicate between two different languages and culturea. The last kinds of translanguaging is translation and interpreting. In a study by Malakoff and Hakuta (1991) translation and interpreting take place in oral or written way consisting of four stages: (a) the comprehension of the vocabulary of the original source-language text: The process of translating and interpreting when the speaker tries to understand the sentence by translating word by word and by making the meaning of the target-language text quite different from that of the sourcelanguage text; (b) the comprehension of the meaning of the original text: The process of translating and interpreting when someone understands the original text, but with the whole lacking a coherent sentence structure or meaning. This may be particularly true in the case of idiomatic expressions, which take their meaning, in part, from their use within the entire sentence. (c) The reformulation of the message of the target language: The process of translating and interpreting take place when the speaker tries to convey the original text from different language into target language without reducing the message delivered and (d) the judgment of the adequacy of the target language text: The abilities of someone to translate and interpret a sentence from original source language based on the level of the sentence. Harris and Sherwood (1978) suggested that interpreting and translating are the skills developed in all bilinguals from the time they begin learning a second language. In other words, translanguaging consists of three kinds, namely code-switching, translating, and language brokering.

\subsection{Translanguaging in the classroom}

The previous studies on translanguaging had some similar findings. Rasman (2018) highlighted that translanguaging occurs in the classroom when the lecturer or students want to finish their explanation, but they lose the word in one language and decide to switch to another language to complete the explanation. It means that translanguaging practice can help the English language learning in context EFL classroom. While Honberger and Link (2012) highlighted that translanguaging practice in the classroom has a potential to appreciate all points of biliteracy context, media, content, and development. The use of English as medium instruction has three main translanguaging practices in EFL classroom: translanguaging is the key of scientific terms in English during the delivery scientific content in Spanish, the use of translanguaging in text or code-switching, talk- around-text in Spanish (Mazak \& Danoso, 2014). Translanguaging as approach in EFL class and report writing is intended to transfer the knowledge from content classes to the lecture class or the use of new note-taking skills across the curriculum (Adamson \& Culson, 2015).

In other studies, translanguaging facilitated the students learning and use of English by incorporating other languages in classroom instruction, but for some students, translanguaging made them difficult to understand of English because their structure or grammar might limit them to express in a correct English (Ke; Lin, 2017). As stated by Carrol and Mazak (2017) some universities in Puerto Rico used translanguaging as Medium Instruction to deliver the materials in English by using English text book. Translanguaging in Japanese students became a media in writing self-regulated learning to achieve their goal in learning English (Garcia; Valesco, 2014). This study showed that translanguaging has some important things in classroom practices, especially in the classroom using more than one language. After having conceptual and empirical literature review, this study employed the construct from Tse (1996) for representing the kinds of translanguaging in compared to Daniel; Pacheco (2016).

\section{Methodology}

The research used qualitative method; in this case, the researcher employed Classroom Discourse Analysis to collect the data. Classroom interaction analysis involved the use of an observation scheme consisting of a finite set of preselected and predetermined categories for describing certain verbal 
behaviors of teachers and students as they interact in the classroom (Kumaravadivelu, 1999). Therefore, this research method enabled the researcher to observe and investigate the interactions in this case dealing with translanguaging as an interaction medium.

\subsection{Setting and participants}

The setting of this research was in higher education context that used more than one language in the classroom. This setting was connected to a phenomenon to use English as an additional language in universities around the world. In the previous plan, the researcher observed two lectures in different classes that often used more than one language to clarify the material and to ascertain the student's comprehension. However, the researcher faced an obstacle that made the researcher moved to another plan. Thus, the researcher only observed one lecturer in the same class.

\subsection{Data collection and research instruments}

During two observations, the researcher observed the lecturer's performance in employing translanguaging to deliver the material. In collecting the data, the researcher used a video tapping. The codification process is based on the instrument below:

Table 1. Observation instrument for codification

\begin{tabular}{|c|c|c|c|c|}
\hline No & Subject & Concept & Component & Sub-Component \\
\hline 1 & $\begin{array}{l}\text { Translan } \\
\text { guaging } \\
\text { Practices }\end{array}$ & $\begin{array}{l}\text { Translanguaging } \\
\text { practices include } \\
\text { code-switching, } \\
\text { language } \\
\text { brokering, } \\
\text { translation and } \\
\text { interpreting } \\
\text { between culturally } \\
\text { and linguistically } \\
\text { diverse individuals } \\
\text { (Tse, 1996) }\end{array}$ & $\begin{array}{l}\text { code- } \\
\text { switching has } \\
\text { focused on } \\
\text { spontaneous } \\
\text { conversation } \\
\text { and written in } \\
\text { two different } \\
\text { languages }\end{array}$ & $\begin{array}{l}\text { a) Inter-sentential switching } \\
\text { b) Intra-sentential switching } \\
\text { c) Tag switching } \\
\text { d) Establishing continuity } \\
\text { with the previous speaker }\end{array}$ \\
\hline
\end{tabular}

\subsection{Data analysis}

Thematic analysis is a method for identifying, analyzing and reporting patterns (themes) within data. Thematic analysis is widely used, and the range of different possible thematic analyses will further be highlighted in relation to a number of decisions regarding it as a method (Braun \& Clarke, 2006).There are six phases/steps of thematic analysis:

Phase 1: Familiarizing myself with the data by keeping the records of all data field notes and transcripts data. The researcher transcribed the result of the observation, and rewatched all data sources as shown in the transcription of verbal data.

Phase 2: Generating initial codes. The researcher made some initial codes to make the constructs simple to be found and recognized.

Phase 3: Searching for themes. The researcher read all the transcription and searches the themes one by one.

Phase 4: Reviewing themes to choose the most appropriate one by comparing the themes. Because in every theme there were some data that had more than one theme, the researcher did some reviews to choose the appropriate theme.

Phase 5: Defining and naming themes.

Phase 6: Producing the report.

\subsection{Data trustworthiness}

The method of the research has been published, confirmed, and reviewed in a journal as trustworthiness. The researcher has reviewed the credibility of this method by the expert judgment with one of lecturer, as Linclon and Guba (1985) suggested that a member of techniques to address credibility including activities such as prolonged engagement, persistent observation, peer debriefing to provide the data on the researcher, and they recommended to re-watch the video recording during the checklist of the table observation.

\section{Findings}

Based on three components employed in the theoretical framework, the teachers fully conducted translanguaging. Those components included code-switching, language brokering, translation and interpretation. From all components, it was found that code-switching, translation and interpretation became the most prominent issues faced by the researcher. In code-switching, the lecturer used to complete the sentence with first or second language. The lecturer also inserted the simple word in the first or second language. Moreover, the lecturer switched from the first language into the second one with some completed sentences. In translation and interpretation, the lecturer uses to clarify the sentence before with the first language. These two sub-themes are displayed in Table (TP/CS/OBS2/545) and (TP/TI/OBS1/507):

T: So, inner speech nya masuk ya, visualnya dapet, terus apalagi?* Kolaborasinya ada ngga? Disini ada kolaborasinya ngga?* (So, there is inner speech, visual too, then what else? *Is there any collaboration here?)

S1: Ada* (Yes, there is) L: Adanya dimana?* How will we collaborate the students in social media? Ada ngga yang nge reply?* (Where is it? *Did anyone reply?)

\section{SS: $\operatorname{Ngga}^{*}(\mathrm{No})$}

(TP/CS/OBS2/545)

L: Iya lah wong tujuannya dia to engage.* Engage apa? Bertunangan?* (His purpose is to engage. *What is engaging? Engagement?)

\section{All: Hahaha}

L: Engage? Melibatkan, saling terlibat jadi ngga dewe-dewe*. Terus yang berikutnya apakah membuat siswa itu mampu untuk mengkontekstualkan?* Ini udah kontekstual belom?* (Engaged? It means to involve, get involved with each other. *Next, whether it makes the students able to contextualize?*Has this been contextual?)

SS: Sudah (Yes)

(TP/TI/OBS1/507) 
The result of the data observation confirmed that translanguaging brought a positive impact when implemented in the classroom. Even though the teacher used English in giving instruction in the classroom, the students still could comprehend it. She realized the students' ability. The lecturer used code switching when the students did not respond to her question, and when she completed the sentence. Moreover, the lecturer used translation and interpretation to help the students to understand the lesson.

There was an interesting finding on code switching practices as one types of translanguaging. There are four types of codeswitching based on Hoffmann (2014) (a) inter-sentential switching; (b) intra-sentential switching; (c) tag switching and (d) establishing continuity with the previous speaker. From the observation data, there were two types of code-switching that were implemented by the lecturer. Those were intra-sentential switching and inter-sentential switching. This concept was frequently used by the lecturer in this research. In terms of intra-sentential switching, the lecturer tended to switch to another language with some simple words in one sentence. The lecturer gave the students warning because many of them were late. She gave the students a reminder not to be late in the next day. Furthermore, she explained that there were certain reasons for being late. When she gave the students warning and reminder she used a second language, and switched to the first language to clarify the previous sentence. On occasion, the lecturer inserted the word in other languages in one sentence. The data intra-sentential switching are provided below:

\section{All S: Under control}

(TP/CS/OBS1/036)

Other data of intra-sentential are presented below. The lecturer gave the students some questions about meaning and kinds of collaboration. In this case, the lecturer used intra-sentential switching as medium instruction. In the first sentence, she used a second language to start her sentence, and finished the sentence with the first language. She also inserted a word in her first language when asking the students.

L: So, the idea of collaboration-nya bener, cuma maksudnya collaboration yang kayak gimana?* Is that collaboration yang pushed by the teacher?* Jerry, what kind of collaboration, yang dimaui Tom itu yang gimana? Apakah kolaborasi yang terpaksa, dipaksa. *Yaa Tiana? (So, the idea of collaboration was true, but what kind of collaboration? *Is that collaboration pushed by the teacher? * What kind of collaboration that Toms' wants, whether collaboration that forced? Ya Tiana?)

\section{S47: Natural}

(TP/CS/OBS2/375)

\section{Discussion}

\subsection{Translanguaging to empower students' learning comprehension}

The theory of Tse (1996) stated that translanguaging practices included code-switching, language brokering, translation and interpreting. During two observation, it was found that the lecturer always used code-switching, translation and interpreting to deliver the materials in the classroom. Meanwhile, language brokering was not found in this research because it usually occurs in small groups or classes with multicultural students.

In terms of inter-sentential switching, the lecturer showed the example of social media used to teach the students in the classroom. She asked the students to identify the kind of principle from social media. The lecturer asked the students a question, she used her first language when asking this question 'is there any collaboration here?' Some of the students were able to answer this question, and the lecturer asked the students another question by using her second language. Even though the question was still related to the previous question, the students did not respond and it triggered a silent moment until the lecturer clarified her question by using her first language. Probably, the students did not understand the material or they were confused with the second language.

Furthermore, the lecturer gave another question with a second language in complete sentence and the students seemed not understand the material or the second language. Thus, the lecturer switched into the first language to make students understand her question. Since the lecturer switched to the first language, there was one student that was able to answer the question. Thus, Translanguaging in this case was used to make the students understand with the instruction.

\subsection{Translanguaging as means to build classroom engagement}

Based on the data observation, the researcher found the emergence of the data. It means that the data were less beyond with the construct as formulated by the researcher. The data found were related to translanguaging practices in the classroom. Commonly, translanguaging is used to understand and to meaning making between teacher and students in the classroom. However, translanguaging has another function to build engagement with the students in the classroom, for example, translanguaging as a joke. In the first data, the lecturer asked the students a question, but no one answered. Then, the lecturer asked one of the students who was daydreaming. Probably, the purpose of the lecturer is to keep the students to focus on the material.

\section{Conclusion}

The researcher investigated the implementation of Translanguaging in higher education. The foundations included code-switching, language brokering, translation and interpretation. It was found out that the lecturer always implemented code switching to facilitate during the material delivery. The lecturer also used translation and interpretation to clarify the material when the students did not understand.

\section{References}

Adamson, J., \& Coulson, D. (2015). Translanguaging in English academic writing preparation. International Journal of Pedagogies and Learning, 10(1), 24-37. 
Braun, V., \& Clarke, V. (2006). Using thematic analysis in psychology. Qualitative research in psychology, 3(2), 77-101.

Canagarajah, S. (2011). Translanguaging in the classroom: Emerging issues for research and pedagogy. Applied linguistics review, 2(2011), 1-28

Carroll, K. S., \& Mazak, C. M. (2017). Language policy in Puerto Rico's higher education: Opening the door for translanguaging practices. Anthropology \& Education Quarterly, 48(1), 4-22.

Creese, A., \& Blackledge, A. (2015). Translanguaging and identity in educational settings. Annual Review of Applied Linguistics, 35, 2035 .

Daniel, S. M., \& Pacheco, M. B. (2016). Translanguaging practices and perspectives of four multilingual teens. Journal of Adolescent \& Adult Literacy, 59(6), 653-663.

Mazak, C. M., \& Herbas-Donoso, C. (2014). Translanguaging practices and language ideologies in Puerto Rican university science education. Critical inquiry in language studies, 11(1), 27-49.

Velasco, P., \& García, O. (2014). Translanguaging and the writing of bilingual learners. Bilingual Research Journal, 37(1), 6-23.

García, O., \& Wei, L. (2014). Translanguaging. The Encyclopedia of Applied Linguistics, 1-7.

Harris, B., \& Sherwood, B. (1978). Translating as an innate skill. In D. Gerver \& H. W. Sinaiko (Eds.), Language interpretation and communication (pp. 155-170). New York: Plenum Press.

Hoffmann, C. (2014). An Introduction to bilingualism. New York, NY: Routledge
Hornberger, N. H., \& Link, H. (2012). Translanguaging in today's classrooms: A biliteracy lens. Theory into practice, 51(4), 239-247.

Ke, I. C., \& Lin, S. (2017). A translanguaging approach to TESOL in Taiwan. English Teaching \& Learning, 41(1), 33-61.

Kumaravadivelu, B. (1999). Critical classroom discourse analysis. TESOL quarterly, 33(3), 453-484.

Li, D. C., \& Elly, C. Y. (2002). One day in the life of a "purist". International Journal of Bilingualism, 6(2), 147-203.

Lincoln, Y. \& Guba, E. G. (1985). Naturalistic inquiry. Newbury Park, CA: SAGE

Malakoff, M., \& Hakuta, K. (1991). Translation skill and metalinguistic awareness in bilinguals. Language processing in bilingual children, $141-166$.

McQuillan, J., \& Tse, L. (1995). Child language brokering in linguistic minority communities: Effects on cultural interaction, cognition, and literacy. Language and Education, 9(3), 195-215.

Moore, D. (2002). Code-switching and learning in the classroom. International journal of bilingual education and bilingualism, 5(5), 279-293.

Rasman, R. (2018). To translanguage or not to translanguage? The multilingual practice in an Indonesian EFL classroom. Indonesian Journal of Applied Linguistics, 7(3), 687-694.

Tse, L. (1996). Language brokering in linguistic minority communities: The case of Chinese-and Vietnamese-American students. Bilingual research journal, 20(3-4), 485-498. 